Case Report

\title{
Primary Pancreatic-Type Acinar Cell Carcinoma of Jejunum Arising from Ectopic Pancreas with Synchronous Metastasis to Left Adrenal Gland
}

\author{
Oliver H. Wang ${ }^{1}$, Priya R. Bhosale ${ }^{2}$, Jeannelyn S. Estrella ${ }^{1, *}$
}

1. Department of Anatomical Pathology, The University of Texas MD Anderson Cancer Center, 1515 Holcombe Blvd., Houston, TX 77030, USA; E-Mails: oliverwang12@gmail.com; jsestrella@mdanderson.org

2. Department of Diagnostic Imaging, The University of Texas MD Anderson Cancer Center, 1515 Holcombe Blvd., Houston, TX 77030, USA; E-Mail: priya.bhosale@mdanderson.org

* Correspondence: Jeannelyn S. Estrella; E-Mail: jsestrella@mdanderson.org

Academic Editor: Tatsuo Kanda

OBM Hepatology and Gastroenterology 2019, volume 3, issue 4

doi:10.21926/obm.hg.1904038
Received: July 08, 2019

Accepted: October 18, 2019

Published: October 28, 2019

\begin{abstract}
Background: Pure pancreatic-type ACC outside the pancreas is extremely rare.

Methods: We presented a very rare case of primary ACC of the pancreatic-type involving jejunum with a synchronous metastasis to left adrenal gland arising in well-developed ectopic pancreas which had fully developed pancreatic acini, islets of Langerhans, ductal structures, pancreatic cancer precursor lesions and a well-formed minor papilla that opens to the mucosal surface of jejunum. We also reviewed all 21 cases of pure pancreatic-type ACC outside the pancreas in the literature.

Results: The pre-operative diagnosis of pancreatic-type ACC outside the pancreas is challenging and difficult based on imaging studies or on small biopsies. Only 2 of 14 cases, which reported a pre-operative diagnosis, were correctly diagnosed as pancreatic-type ACC on liver biopsy. Patients who presented with unresectable or stage IV disease had mean overall survival of 13.5 (standard deviation [SD], 4.2) months, which was shorter than those who underwent surgical resection with curative intent (mean: $54.3,[S D, 9.1]$ months, $P=$ 0.008).
\end{abstract}

Conclusions: The pre-operative diagnosis of pancreatic-type ACC outside the pancreas is

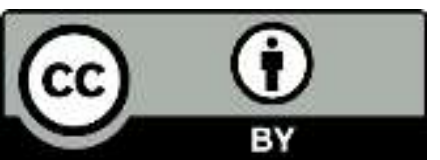

(C) 2019 by the author. This is an open access article distributed under the conditions of the Creative Commons by Attribution License, which permits unrestricted use, distribution, and reproduction in any medium or format, provided the original work is correctly cited. 
challenging. Early detection and surgical resection may prolong survival in these patients.

\section{Keywords}

Pancreatic acinar cell carcinoma; ectopic pancreas; survival

\section{Introduction}

Pancreatic acinar cell carcinoma (ACC) is a rare neoplasm, accounting for only about $1 \%-2 \%$ of all exocrine tumors of the pancreas [1]. Pure pancreatic-type ACC outside the pancreas, arising from ectopic pancreatic tissue or pancreatic acinar cell metaplasia, is extremely rare. In the literature, only 21 cases of pure ACC of pancreatic-type have been reported: six in the stomach [27], nine in liver [8-13], one in the duodenum [14], one in the ampulla of Vater [15], two in the jejunum [16, 17], one in the sigmoid colon [18], and one in lesser omentum [19]. Among these reported cases, ectopic pancreatic tissue or pancreatic acinar cell metaplasia was present in only two cases $[2,16]$. In this report, we presented an extremely rare case of pure pancreatic-type ACC of jejunum with a synchronous metastasis to left adrenal gland arising in well-developed ectopic pancreas which had fully developed pancreatic acini, islets of Langerhans, ductal structures, pancreatic intraepithelial neoplasia and a well-formed minor papilla that opens to the mucosal surface of jejunum. We also reviewed the clinicopathologic features and follow-up data of all 21 cases of pancreatic-type ACC arising from ectopic pancreas in the literature.

\section{Case Presentation}

The patient was a 64 year-old Caucasian gentleman with a long history of morbid obesity, type 2 diabetes mellitus, hypertension, hyperlipidemia, coronary artery disease, cardiac arrhythmias, and sleep apnea. The patient had no personal or family history of cancer. Even with adjustments to his blood pressure medications, control of his blood pressure could not be achieved, with baseline blood pressure of $180 / 105 \mathrm{~mm} \mathrm{Hg}$. Imaging studies showed a large mass measuring $7.0 \mathrm{~cm}$ in the left adrenal gland and bilateral multiple renal cysts, the largest measuring $3.3 \mathrm{~cm}$ in the upper pole of the left kidney. He was referred to our hospital for further evaluation and treatment. Extensive hormonal and laboratory work up was performed. He was found to have iron deficiency anemia (hemoglobin: $7.2 \mathrm{~g} / \mathrm{dl}$ ), which was treated with 4 units of blood transfusion followed by oral iron pills. No evidence of hormonal overproduction was found with normal levels of renin $\quad<0.6$ $\mathrm{ng} / \mathrm{ml} / \mathrm{h})$, aldosterone $(10 \mathrm{ng} / \mathrm{dl})$, free normetanephrine $(0.78 \mathrm{nmol} / \mathrm{L})$, free metanephrine $(<0.2$ $\mathrm{nmol} / \mathrm{L})$, serum cortisol $(4.3 \mathrm{mcg} / \mathrm{dl})$, ACTH $(10 \mathrm{pg} / \mathrm{ml})$, dehydroepiandrosterone sulfate $(<15$ $\mathrm{mcg} / \mathrm{dl}$ ), and a negative low dose dexamethasone suppression test. He had no fever, changes in skin color, jaundice, abdominal pain, melena, bloody stool, hematuria, or any other bleeding. A colonoscopy as well as upper gastrointestinal endoscopy were performed by an outside gastroenterologist who reported diffuse gastritis and benign colon polyps, but otherwise unremarkable endoscopic findings. The follow-up abdominal computed tomography (CT) scan performed at our institution 3.5 months after the initial imaging study showed, in addition to the bilateral renal cysts, a slight increase in size of the left adrenal mass $(7.2 \mathrm{~cm})$ and areas of 
calcification and fat necrosis in the omentum (Figure 1). There was no significant lymphadenopathy. The liver, pancreas, spleen, right adrenal gland and gallbladder were unremarkable. Chest CT scan showed calcified and non-calcified nodules up to $4 \mathrm{~mm}$ in size in the right lung, suggestive of granulomatous disease. The clinical and radiological findings favored the diagnosis of adrenal cortical carcinoma. Given the known potential for peritoneal seeding associated with biopsy of adrenocortical carcinoma, the decision was made to perform an open laparotomy and resection of the left adrenal mass. At the time of surgery, the patient was found to have areas of concern for metastasis in both lobes of the liver, spleen, and peritoneal surfaces, including the diaphragm, omentum, and pelvis. The planned left adrenalectomy was aborted. Upon examination of the small intestine and colon, a tumor within the jejunum was identified at approximately 10 inches distal to the ligament of Treitz that appeared to be partially obstructing the lumen. No other concerning lesions were identified. Segmental resection of the small bowel and resection of a $4 \mathrm{~cm}$ omental tumor were performed and sent for an intra-operative evaluation, which reported a frozen section diagnosis of neuroendocrine tumor in the small intestine and calcification, ossification and chronic inflammation in the omentum. Pathologic examination of the resected segment of small intestine $(7 \mathrm{~cm}$ in length) revealed an ulcerated mass $(4 \times 3.5 \times 1.8 \mathrm{~cm})$ with a tan-white cut surface. Grossly, the tumor involved the muscular wall and extended into the subserosal soft tissue. The tumor was $2 \mathrm{~cm}$ from the closest small intestinal margin. In the subserosa and muscularis propria of small intestine adjacent to the tumor, there was a large area of tan-yellow lobulated tissue $(4.0 \times 3.5 \times 1.2 \mathrm{~cm})$, consistent with ectopic pancreas (Figure $2 \mathrm{~A})$. The rest of the small intestine was grossly unremarkable. Microscopically, the tumor invaded into, but not through, the muscularis propria. The tumor consisted of tumor cells forming solid sheets with an acinar pattern. The tumor cells had uniform nuclei, inconspicuous nucleoli, and purple granules in the cytoplasm. More than 10 mitotic figures per 10 high power fields were identified (Figure 3A-3C). Lymphovascular invasion was present. Immunohistochemical stains show that the tumor was positive for pancytokeratin and trypsin (Figure 3D-3E). The tumor cells were negative for chromogranin A (Figure 3F), synaptophysin, inhibin and HMB-45 (data not shown). Sections from the area of lobulated soft tissue showed an ectopic pancreas which had fully developed pancreatic acini, islets of Langerhans, ductal structures, a well-formed ductal complex mimicking pancreatic duct of Santorini, and minor papilla which opened to the mucosal surface of the jejunum and focal pancreatic intraepithelial neoplasia 1 and 2 (PanIN 1 and PanIN 2, Figure 2B-2D). The ectopic pancreas was predominately located in the muscularis propria and focally extended into the submucosa and subserosa. Therefore, the final diagnosis of primary acinar cell carcinoma of the pancreatic-type arising in ectopic pancreas of the jejunum was made. The frozen section diagnosis in the omentum was confirmed, and no carcinoma was identified. No lymph nodes were grossly or microscopically identified since there was only limited mesenteric adipose tissue present in the specimen. The pathologic stage was pT2,Nx,M1 (adrenal gland). 

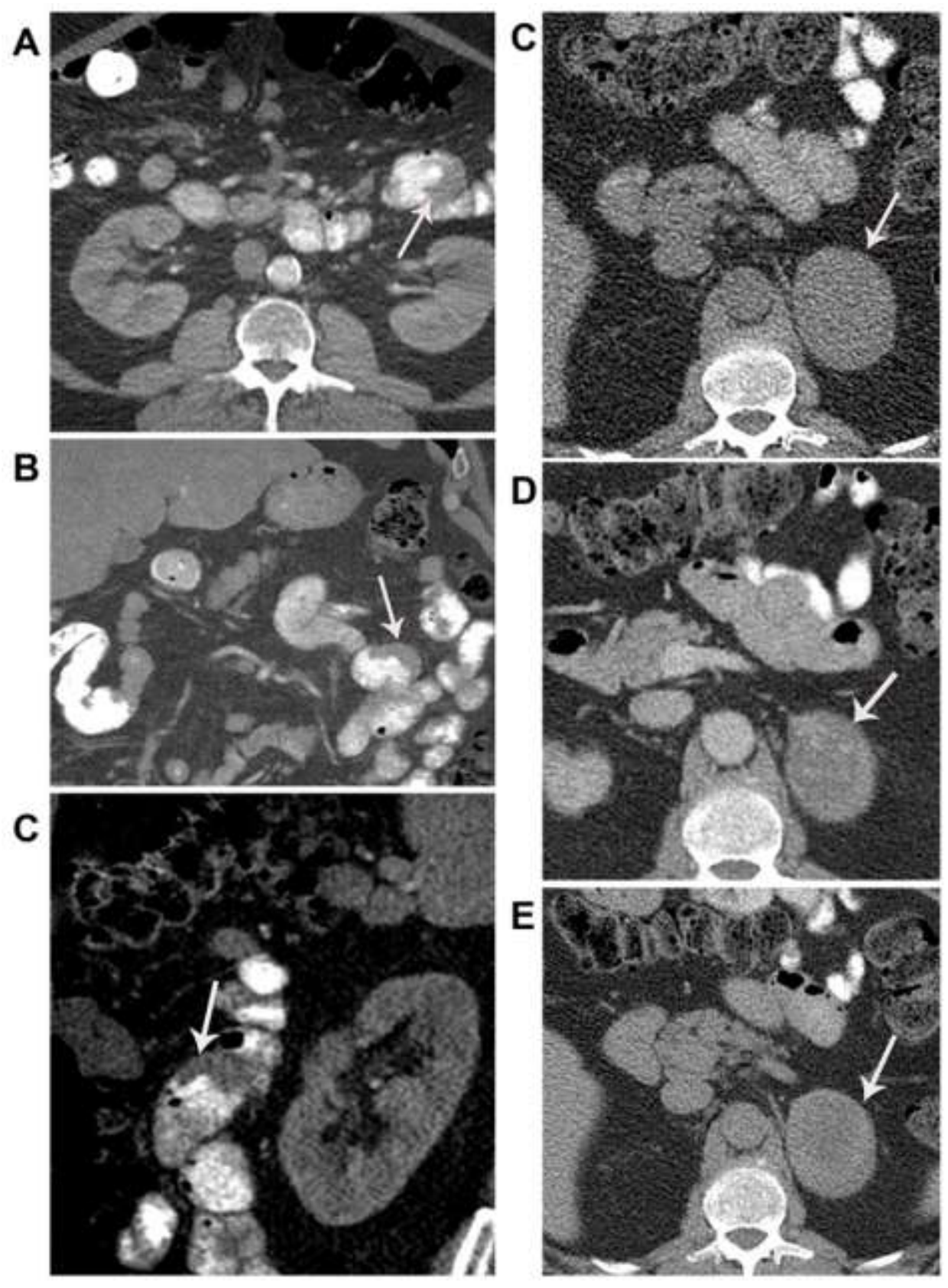

Figure 1 The axial (A), coronal (B) and sagittal (C) images show a mass (arrow) in the jejunal loop which is hypoattenutating to the contrast present in the bowel loops. The axial precontrast (C), portal venous phase (D) and delayed (E) images show a mass (arrow) in the left adrenal gland which demonstrates contrast enhancement and washout. 

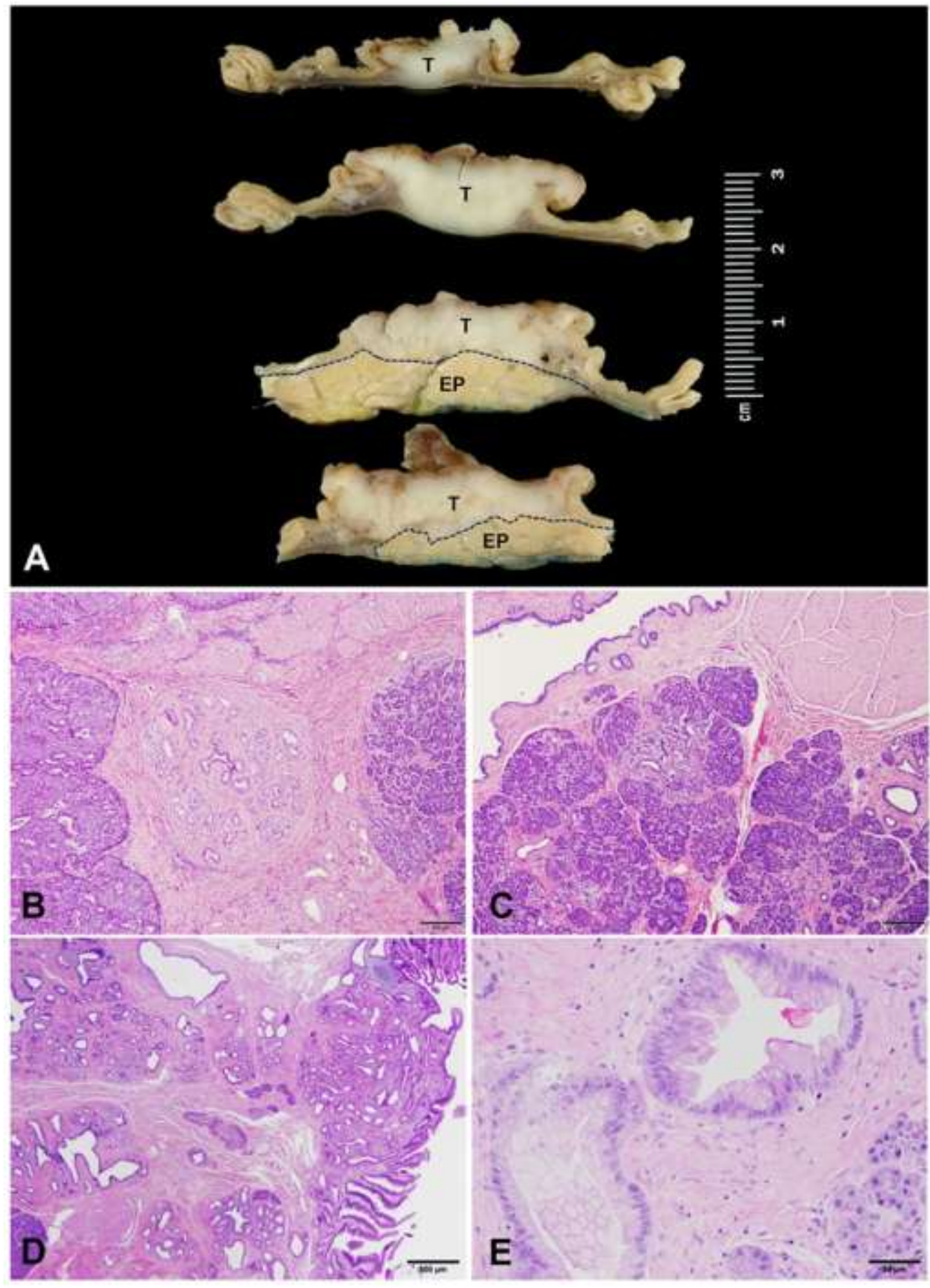

Figure 2 (A) Cross sections of tumor (T) with underlying ectopic pancreas (EP). (B) H\&Estained section of the interface between the tumor and non-neoplastic ectopic pancreas (40x). (C-E) H\&E-stained sections of ectopic pancreas exhibiting fully developed pancreatic acini, islets of Langerhans, ductal structures (C, 40x), a wellformed ductal complex mimicking pancreatic duct of Santorini and minor papilla which opened to the mucosal surface of jejunum (D, 20x) and focal pancreatic intraepithelial neoplasia 1 and 2 (E, 100x). 

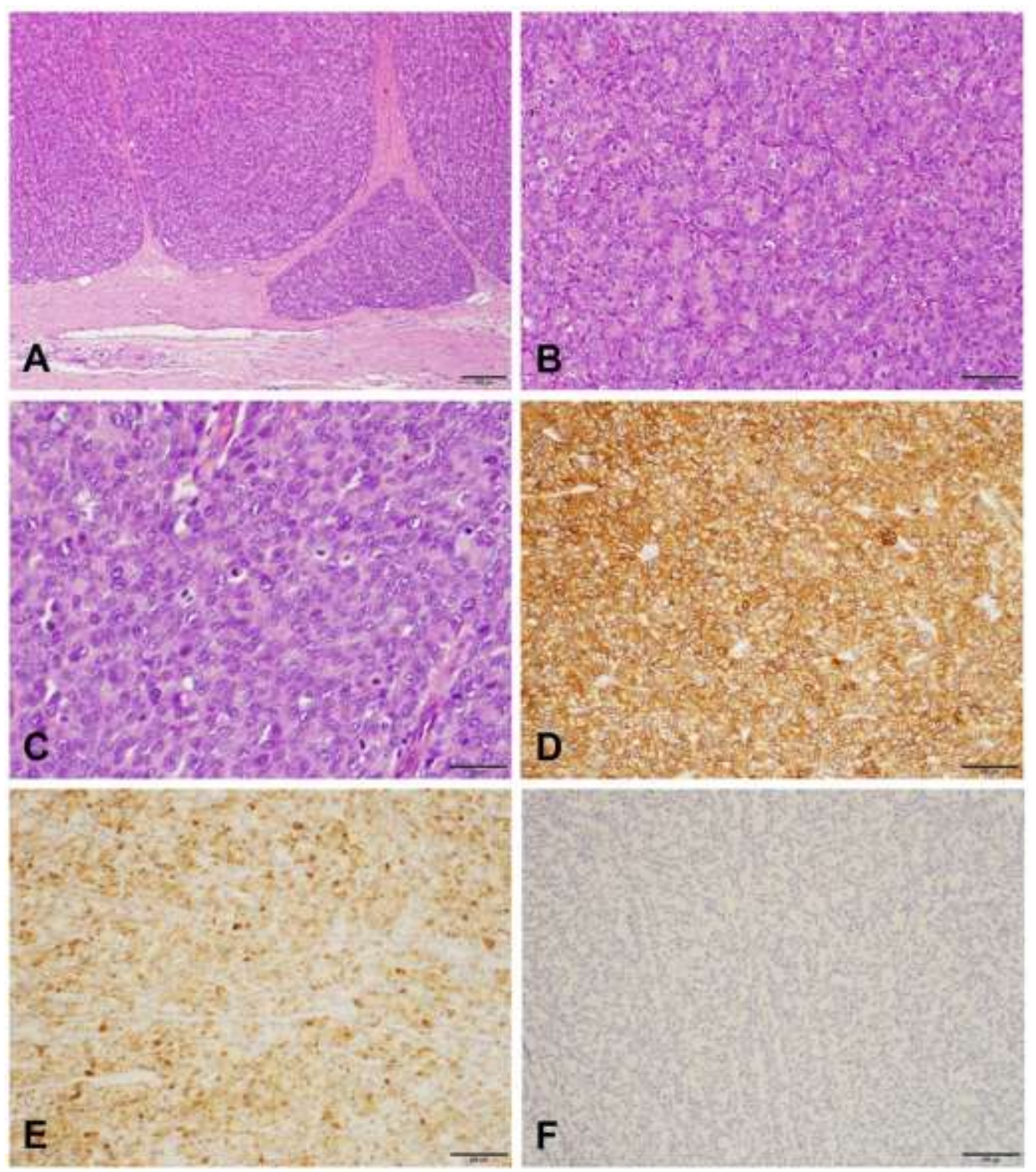

Figure $3(A-C) H \& E$ sections of tumor invading into the muscularis propria $(A, 40 x)$, exhibiting acinar pattern $(B, 100 x)$ and solid sheets with brisk mitosis (C, 200x). The tumor is positive for pancytokeratin $(D, 100 x)$ and trypsin $(E, 100 x)$, but negative for chromogranin $A(F, 100 x)$.

The patient tolerated the procedure well with no complications and fully recovered one month after surgery. Subsequent fine needle aspiration of the left adrenal mass confirmed the diagnosis of metastatic acinar cell carcinoma. Patient elected to receive no adjuvant chemotherapy. He was closely followed by multiple abdominal and thoracic CT or PET/CT scans every three months. The follow up scans showed a stable tumor in the left adrenal gland, normal pancreas, and no additional FDG-avid foci during the first eight months. However, 14 months post surgery, the patient developed bilobar hepatic metastases, recurrence in the mesentery adjacent to the site of jejunal resection, and progression of left adrenal tumor. The patient was then treated with Gemzar. The patient died of metastatic ACC, 18 months post surgery and 22 months from the initial imaging diagnosis. 


\section{Discussion}

Malignant transformation of ectopic pancreas is extremely rare. The proposed criteria for carcinoma arising from ectopic pancreatic tissue include the following: (1) tumor is found within or near the ectopic pancreas; (2) a transition between non-neoplastic pancreatic tissue and carcinoma should be present, and (3) fully developed pancreatic acini and ductal structures should be present in the ectopic pancreatic tissue [20]. Our case fits all of the above criteria, with the ectopic pancreas exhibiting fully developed pancreatic acini, islets of Langerhans and ductal structures, a well-formed ductal complex mimicking pancreatic duct of Santorini, and a minor papilla that opens to the mucosal surface of the jejunum. Pancreatic intraepithelial neoplasia 1 and 2 (PanIN1 and PanIN2) were also present in the non-neoplastic pancreas in our case. In 19 of 21 previously reported cases, the ectopic pancreas was not identified, but operated with the assumption that the ACC arose from ectopic pancreas which was completely obliterated by the tumor.

Among the 22 reported cases, including our case, 12 were male and 10 were female with age ranging from 6 years to 86 years (median age: 64.5 years). The most common reported site is liver (9/22, 40.9\%), followed by stomach (6/21, 27.3\%), duodenum and jejunum $(4 / 22,18.2 \%$, Table 1$)$. Patients often presented with non-specific symptoms such as abdominal discomfort/pain, weight loss, anemia, etc. or the tumor was identified during workup for other causes. Given the rarity of this entity, the pre-operative diagnosis based on imaging studies or on small biopsies is challenging and difficult. Among the 14 cases which reported a pre-operative diagnosis, six were diagnosed as poorly differentiated adenocarcinoma/carcinoma on biopsy and six were diagnosed as hepatocellular carcinoma, gastrointestinal stromal tumor (GIST) vs lymphoma or cholangiocarcinoma based on imaging or endoscopic studies. Only two cases were correctly diagnosed as an ACC of the pancreatic-type on liver biopsy.

Treatment information, when available, varied among patients. Eighteen patients were treated with surgical resection, with three receiving adjuvant chemotherapy as well. One patient with gastric ACC of the pancreatic-type had synchronous pancreatic ductal adenocarcinoma with lymph node and liver metastases and was treated with up-front chemotherapy. The final diagnosis of gastric ACC of the pancreatic-type was only made on autopsy after the patient died, 5 months post diagnosis. One patient received steroid therapy for skin lesions secondary to lipase hypersecretion syndrome. Two patients with non-resectable liver tumors were treated with chemotherapy alone. 
Table 1 The Clinical and pathologic features of 22 cases of pancreatic-type acinar cell carcinoma outside the pancreas.

\begin{tabular}{|c|c|c|c|c|c|c|c|c|c|c|}
\hline Case & Age & Gender & $\begin{array}{l}\text { Presenting } \\
\text { symptom(s) }\end{array}$ & Tumor Site & $\begin{array}{l}\text { Preoperative } \\
\text { Diagnosis }\end{array}$ & $\begin{array}{l}\text { Tumor Size and } \\
\text { Characteristics }\end{array}$ & Treatment & $\begin{array}{l}\text { Recurrence } \\
\text { (months) }\end{array}$ & $\begin{array}{l}\text { Outcome } \\
\text { (months) }\end{array}$ & $\begin{array}{l}\text { Author(s) } \\
\text { [References] }\end{array}$ \\
\hline 1 & 52 & $\mathrm{M}$ & $\begin{array}{l}\text { Exacerbated } \\
\text { dyspeptic } \\
\text { symptoms }\end{array}$ & Gastric Antrum & Adenocarcinoma & $\begin{array}{l}4.0 \mathrm{~cm} \text {, ulcerated } \\
\text { tumor invading } \\
\text { submucosa }\end{array}$ & Subtotal gastrectomy & No & NA & $\begin{array}{l}\text { Ambrosini- } \\
\text { Spaltro, et al } \\
\text { [2] }\end{array}$ \\
\hline 2 & 86 & $\mathrm{~F}$ & $\begin{array}{l}\text { Identified during } \\
\text { work up for } \\
\text { anemia }\end{array}$ & Gastric Antrum & Adenocarcinoma & $\begin{array}{l}5.0 \mathrm{~cm} \text {, ulcerated } \\
\text { tumor invading } \\
\text { muscularis propria }\end{array}$ & Partial gastrectomy & No & NA & $\begin{array}{l}\text { Sun and } \\
\text { Wasserman } \\
{[6]}\end{array}$ \\
\hline 3 & 73 & $M$ & Epigastralgia & Gastric Pylorus & GIST vs lymphoma & $\begin{array}{l}7.6 \mathrm{~cm} \text {, submucosal } \\
\text { mass invading } \\
\text { pancreas with LN } \\
\text { metastasis }\end{array}$ & Pancreaticoduodenectomy & Liver (7) & AWD (11) & Mizuno [5] \\
\hline 4 & 63 & M & $\begin{array}{l}\text { Abdominal pain, } \\
\text { weight loss }\end{array}$ & Gastric Antrum & Adenocarcinoma & $\begin{array}{l}6.5 \mathrm{~cm} \text {, ulcerated } \\
\text { mass with liver } \\
\text { metastasis }\end{array}$ & Chemotherapy & No & DOD (5) & $\begin{array}{l}\text { Yonenaga } \\
\text { [7] }\end{array}$ \\
\hline 5 & 77 & $\mathrm{~F}$ & Anemia & Gastric fundus & $\begin{array}{l}\text { Poorly } \\
\text { differentiated } \\
\text { carcinoma }\end{array}$ & $\begin{array}{l}4.5 \mathrm{~cm} \text {, polypoid and } \\
\text { exophyitic mass } \\
\text { invading MP }\end{array}$ & Partial gastrectomy & No & $\begin{array}{l}\text { Died, } \\
\text { complications } \\
(1)\end{array}$ & Coyne [3] \\
\hline 6 & 54 & M & $\begin{array}{l}\text { Detected by } \\
\text { endoscopy }\end{array}$ & Gastric cardia & GIST vs lymphoma & $\begin{array}{l}2.7 \mathrm{~cm} \text {, well- } \\
\text { circumscribed } \\
\text { submucosal mass }\end{array}$ & $\begin{array}{l}\text { Laparoscopic wedge } \\
\text { resection }\end{array}$ & No & NED (33) & $\operatorname{Kim}[4]$ \\
\hline
\end{tabular}




\begin{tabular}{|c|c|c|c|c|c|c|c|c|c|c|}
\hline 7 & 35 & $\mathrm{~F}$ & $\begin{array}{l}\text { Abdominal pain, } \\
\text { weight loss }\end{array}$ & Liver, left & $\begin{array}{l}\text { Hepatocellular } \\
\text { carcinoma }\end{array}$ & $\begin{array}{l}4.0 \mathrm{~cm} \text {, polycystic, } \\
\text { unencapsulated } \\
\text { mass }\end{array}$ & Left hepatectomy & No & NED (72) & Hervieu [9] \\
\hline 8 & 73 & $\mathrm{~F}$ & $\begin{array}{l}\text { Painful } \\
\text { cutaneous } \\
\text { lesions }\end{array}$ & $\begin{array}{l}\text { Liver, right and } \\
\text { left }\end{array}$ & NA & $\begin{array}{l}1.0-6.0 \mathrm{~cm}, \text { multiple } \\
\text { liver masses }\end{array}$ & $\begin{array}{l}\text { Steroid treatment for skin } \\
\text { lesions }\end{array}$ & No & $\operatorname{DOD}(2.5)$ & Zundler [13] \\
\hline 9 & 68 & $\mathrm{~F}$ & Weight loss & Liver, left & $\begin{array}{l}\text { Hepatocellular } \\
\text { carcinoma }\end{array}$ & $\begin{array}{l}7.0 \mathrm{~cm} \text {, well- } \\
\text { circumscribed mass }\end{array}$ & Partial hepatectomy & No & NED (38) & Agaimy [8] \\
\hline 10 & 71 & $M$ & Abdominal pain & Liver, right & $\begin{array}{l}\text { Hepatocellular } \\
\text { carcinoma }\end{array}$ & $\begin{array}{l}\text { Size not reported, } \\
\text { mass }\end{array}$ & $\begin{array}{l}\text { Right hemihepatectomy } \\
\text { with hepaticojejunostomy }\end{array}$ & No & $\begin{array}{l}\text { Died, } \\
\text { unknown (3) }\end{array}$ & Agaimy [8] \\
\hline 11 & 72 & $M$ & $\begin{array}{l}\text { Abdominal } \\
\text { discomfort }\end{array}$ & Liver, right & Cholangiocarcinoma & $\begin{array}{l}\text { Size not reported, } \\
\text { large mass }\end{array}$ & Hepatectomy & Liver (18) & AWD (20) & Agaimy [8] \\
\hline 12 & 49 & $\mathrm{~F}$ & $\begin{array}{l}\text { Abdominal } \\
\text { discomfort }\end{array}$ & Liver, right & NA & $\begin{array}{l}\text { Size not reported, } \\
\text { multinodular mass }\end{array}$ & Right hepatectomy & No & NED (28) & Agaimy [8] \\
\hline 13 & 54 & $\mathrm{~F}$ & $\begin{array}{l}\text { Early satiety, } \\
\text { abdominal } \\
\text { discomfort }\end{array}$ & Liver, right & NA & $\begin{array}{l}16.9 \text { and } 3.0 \mathrm{~cm}, 2 \\
\text { masses }\end{array}$ & $\begin{array}{l}\text { Right hepatectomy plus } \\
\text { chemotherapy }\end{array}$ & No & AWD (20) & Jordan [10] \\
\hline 14 & 48 & $M$ & Jaundice & Liver, right & $\begin{array}{l}\text { Acinar cell } \\
\text { carcinoma }\end{array}$ & $15 \mathrm{~cm}$, mass & Chemotherapy & No & AWD (13) & Laino [11] \\
\hline 15 & 31 & $M$ & Abdominal pain & $\begin{array}{l}\text { Liver, right and } \\
\text { left }\end{array}$ & $\begin{array}{l}\text { Acinar cell } \\
\text { carcinoma }\end{array}$ & $\begin{array}{l}\text { Size not reported, } \\
\text { large mass }\end{array}$ & Chemotherapy & $\begin{array}{l}\text { Lung and } \\
\text { LN }\end{array}$ & DOD (18) & $\begin{array}{l}\text { Wildgruber } \\
\text { [12] }\end{array}$ \\
\hline 16 & 58 & $M$ & $\begin{array}{l}\text { Iron deficiency } \\
\text { anemia }\end{array}$ & $\begin{array}{l}\text { Duodenum, } \\
\text { 2nd part }\end{array}$ & NA & $\begin{array}{l}2.7 \mathrm{~cm} \text {, submucosal } \\
\text { mass }\end{array}$ & $\begin{array}{l}\text { Duodenectomy plus } \\
\text { chemotherapy }\end{array}$ & No & NED (18) & Jharomi [14] \\
\hline
\end{tabular}




\begin{tabular}{|c|c|c|c|c|c|c|c|c|c|c|}
\hline 17 & 65 & $\mathrm{~F}$ & $\begin{array}{l}\text { Jaundice and } \\
\text { fatigue }\end{array}$ & $\begin{array}{l}\text { Ampulla of } \\
\text { Vater }\end{array}$ & $\begin{array}{l}\text { Carcinoma of } \\
\text { ampulla of Vater }\end{array}$ & $\begin{array}{l}1.2 \mathrm{~cm} \text {, submucosal } \\
\text { mass invading } \\
\text { duodenal MP }\end{array}$ & Pancreaticoduodenectomy & No & NED (19) & $\begin{array}{l}\text { Kawakami } \\
{[15]}\end{array}$ \\
\hline 18 & 71 & M & $\begin{array}{l}\text { Incidental } \\
\text { (during } \\
\text { cholecystectomy) }\end{array}$ & $\begin{array}{l}\text { Proximal } \\
\text { jejunum }\end{array}$ & NA & $\begin{array}{l}3.5 \mathrm{~cm} \text {, ulcerated } \\
\text { mass invading } \\
\text { subserosa }\end{array}$ & Segmental resection & Liver (12) & AWD (12) & $\begin{array}{l}\text { Makhlouf } \\
{[16]}\end{array}$ \\
\hline 19 & 78 & $\mathrm{~F}$ & Melena & Jejunum & Adenocarcinoma & $\begin{array}{l}8.5 \mathrm{~cm} \text {, exophytic } \\
\text { mass invading } \\
\text { mesenteric tissue }\end{array}$ & $\begin{array}{l}\text { Partial jejunectomy, } \\
\text { partial pancreatectomy } \\
\text { plus chemotherapy }\end{array}$ & No & NED (10) & Takagi [17] \\
\hline 20 & 65 & $\mathrm{~F}$ & $\begin{array}{l}\text { Intestinal } \\
\text { obstruction }\end{array}$ & Sigmoid colon & NA & $\begin{array}{l}4.0 \mathrm{~cm} \text {, ulcerated } \\
\text { tumor invading } \\
\text { ipericolonic tissue } \\
\text { with LN metastasis }\end{array}$ & Segmental resection & Femur (18) & DOD (24) & $\begin{array}{l}\text { Chiaravalli } \\
{[18]}\end{array}$ \\
\hline 21 & 6 & M & Abdominal pain & $\begin{array}{l}\text { Lesser } \\
\text { omentum }\end{array}$ & NA & $\begin{array}{l}12 \mathrm{~cm} \text {, mass with no } \\
\text { involvement of } \\
\text { pancreas }\end{array}$ & Omentectomy & No & NED (5) & Sharma [19] \\
\hline 22 & 64 & M & $\begin{array}{l}\text { Incidental (work } \\
\text { up for blood } \\
\text { pressure) }\end{array}$ & Jejunum & NA & $\begin{array}{l}4.0 \mathrm{~cm} \text {, ulcerated } \\
\text { mass with left } \\
\text { adrenal gland } \\
\text { metastasis }\end{array}$ & Segmental resection & $\begin{array}{l}\text { Mesentery, } \\
\text { liver (14) }\end{array}$ & DOD (22) & Our case \\
\hline
\end{tabular}


Follow-up information was available in 20 patients. During follow-up, one patient with gastric ACC and one patient with jejunal ACC developed liver metastasis after surgical resection at 7 and 12 months, respectively. One patient with liver ACC had liver recurrence at 18 months. One patient with ACC of the colon developed metastasis in the femur at 18 months after colectomy. Our patient developed bilobar hepatic metastases, recurrence in the mesentery adjacent to the site of jejunal resection, and progression of left adrenal tumor at 14 months after surgery. Five patients died of disease at 2.5, 5, 18, 22, and 24 months respectively, one patient died of surgical complications at 1 month and one patient died of unknown cause at 3 months. Five were alive with disease and eight were alive with no evidence of disease with a follow up of 5 to 72 months. The median overall survival was 24 months. Patients who presented with unresectable or stage IV disease had mean overall survival of 13.5 (standard deviation [SD], 4.2) months, which was shorter than those who underwent surgical resection with curative intent (mean: 54.3, [SD, 9.1] months, $P$ $=0.008$, Figure 4).

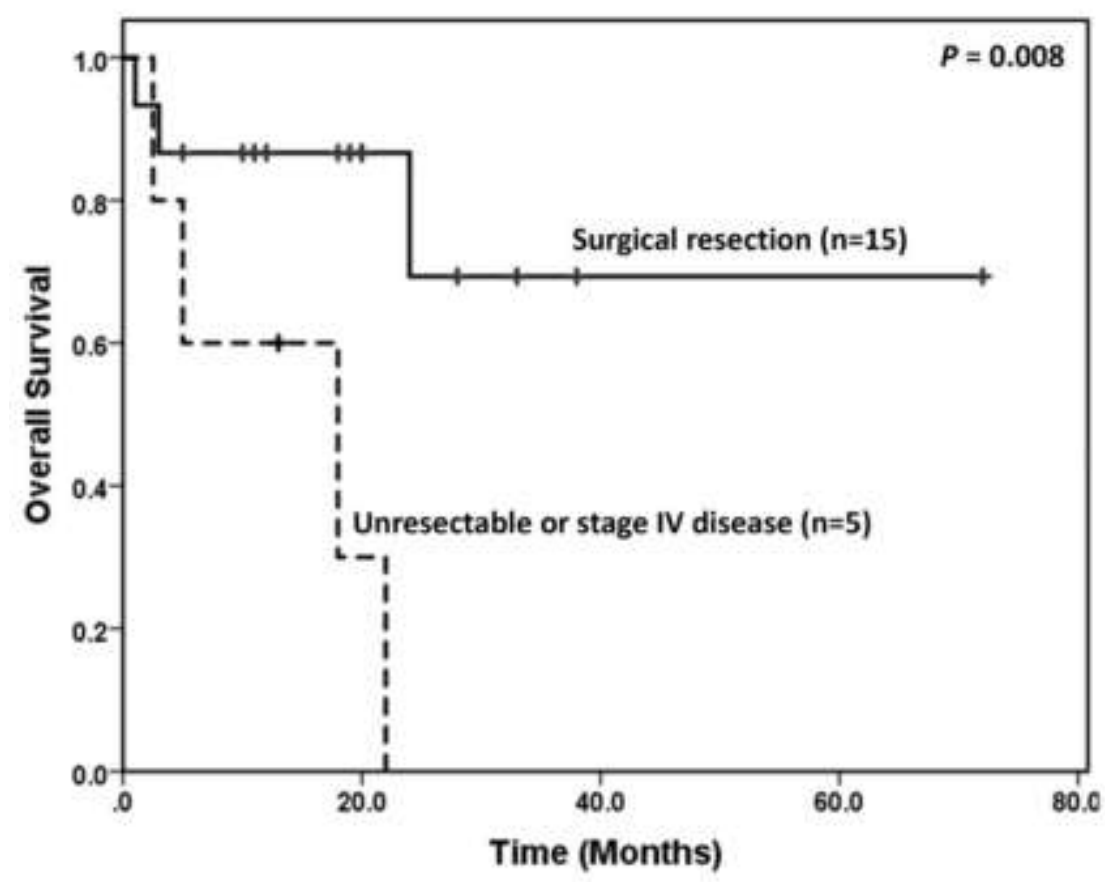

Figure 4 Kaplan-Meier survival curves showing patients with unresectable or stage IV disease had shorter overall survival than those who underwent surgical resection with curative intent $(P=0.008)$.

In this report, we presented a very rare case of primary ACC of the pancreatic-type involving jejunum with synchronous metastasis to left adrenal gland arising in well-developed ectopic pancreas which had fully developed pancreatic acini, islets of Langerhans, ductal structures, pancreatic precursor lesions, and a well-formed minor papilla that opens to the mucosal surface of jejunum. Given the rarity of this tumor, ACC of the pancreatic-type is difficult to diagnose in other organs outside of the pancreas, clinically and on small biopsy when ectopic pancreas is not sampled. Considering that patients who underwent resection with curative intent had better overall survival, based on a limited number of cases reports, early detection and surgical resection may prolong survival in these patients. 


\section{Author Contributions}

OHW - writing and editing of manuscript, Figure 2 and Figure 3 construction; PRB - Figure 1 construction; JSE - writing and editing of manuscript.

\section{Competing Interests}

The authors have declared that no competing interests exist.

\section{References}

1. Holen KD, Klimstra DS, Hummer A, Gonen M, Conlon K, Brennan M, et al. Clinical characteristics and outcomes from an institutional series of acinar cell carcinoma of the pancreas and related tumors. J Clin Oncol. 2002; 20: 4673-4678.

2. Ambrosini-Spaltro A, Poti O, De Palma M, Filotico M. Pancreatic-type acinar cell carcinoma of the stomach beneath a focus of pancreatic metaplasia of the gastric mucosa. Hum Pathol. 2009; 40: 746-749.

3. Coyne JD. Pure pancreatic-type acinar cell carcinoma of the stomach: A case report. Int J Surg Pathol. 2012; 20: 71-73.

4. Kim KM, Kim CY, Hong SM, Jang KY. A primary pure pancreatic-type acinar cell carcinoma of the stomach: A case report. Diagn Pathol. 2017; 12: 10.

5. Mizuno $Y$, Sumi $Y$, Nachi S, Ito $Y$, Marui T, Saji S, et al. Acinar cell carcinoma arising from an ectopic pancreas. Surg Today. 2007; 37: 704-707.

6. Sun Y, Wasserman PG. Acinar cell carcinoma arising in the stomach: A case report with literature review. Hum Pathol. 2004; 35: 263-265.

7. Yonenaga $Y$, Kurosawa M, Mise M, Yamagishi M, Higashide S. Pancreatic-type acinar cell carcinoma of the stomach included in multiple primary carcinomas. Anticancer Res. 2016; 36: 2855-2864.

8. Agaimy A, Kaiser A, Becker K, Brasen JH, Wunsch PH, Adsay NV, et al. Pancreatic-type acinar cell carcinoma of the liver: A clinicopathologic study of four patients. Mod Pathol. 2011; 24: 1620-1626.

9. Hervieu V, Lombard-Bohas C, Dumortier J, Boillot O, Scoazec JY. Primary acinar cell carcinoma of the liver. Virchows Arch. 2008; 452: 337-341.

10. Jordan EJ, Basturk O, Shia J, Klimstra DS, Alago W, D'Angelica MI, et al. Case report: Primary acinar cell carcinoma of the liver treated with multimodality therapy. J Gastrointest Oncol. 2017; 8: E65-E72.

11. Laino ME, Ragucci M, Klimstra DS, Mannelli L. Hepatobiliary and pancreatic: Primary acinar cell carcinoma of the liver showing good response to chemotherapy. J Gastroenterol Hepatol. 2018; 33: 977.

12. Wildgruber M, Rummeny EJ, Gaa J. Primary acinar cell carcinoma of the liver. Rofo. 2013; 185: 572-573.

13. Zundler S, Erber R, Agaimy A, Hartmann A, Kiesewetter F, Strobel D, et al. Pancreatic panniculitis in a patient with pancreatic-type acinar cell carcinoma of the liver--case report and review of literature. BMC Cancer. 2016; 16: 130. 
14. Hamidian Jahromi A, Shokouh-Amiri H, Wellman G, Hobley J, Veluvolu A, Zibari GB. Acinar cell carcinoma presenting as a duodenal mass: Review of the literature and a case report. $\mathrm{J}$ La State Med Soc. 2013; 165: 20-23, 25.

15. Kawakami H, Kuwatani M, Onodera M, Hirano S, Kondo S, Nakanishi $Y$, et al. Primary acinar cell carcinoma of the ampulla of Vater. J Gastroenterol. 2007; 42: 694-697.

16. Makhlouf HR, Almeida JL, Sobin LH. Carcinoma in jejunal pancreatic heterotopia. Arch Pathol Lab Med. 1999; 123: 707-711.

17. Takagi K, Yagi T, Tanaka T, Umeda Y, Yoshida R, Nobuoka D, et al. Primary pancreatic-type acinar cell carcinoma of the jejunum with tumor thrombus extending into the mesenteric venous system: A case report and literature review. BMC Surg. 2017; 17: 75.

18. Chiaravalli AM, Finzi G, Bertolini V, La Rosa S, Capella C. Colonic carcinoma with a pancreatic acinar cell differentiation. A case report. Virchows Arch. 2009; 455: 527-531.

19. Sharma S, Agarwal S, Nagendla MK, Gupta DK. Omental acinar cell carcinoma of pancreatic origin in a child: A clinicopathological rarity. Pediatr Surg Int. 2016; 32: 307-311.

20. Guillou L, Nordback P, Gerber C, Schneider RP. Ductal adenocarcinoma arising in a heterotopic pancreas situated in a hiatal hernia. Arch Pathol Lab Med. 1994; 118: 568-571

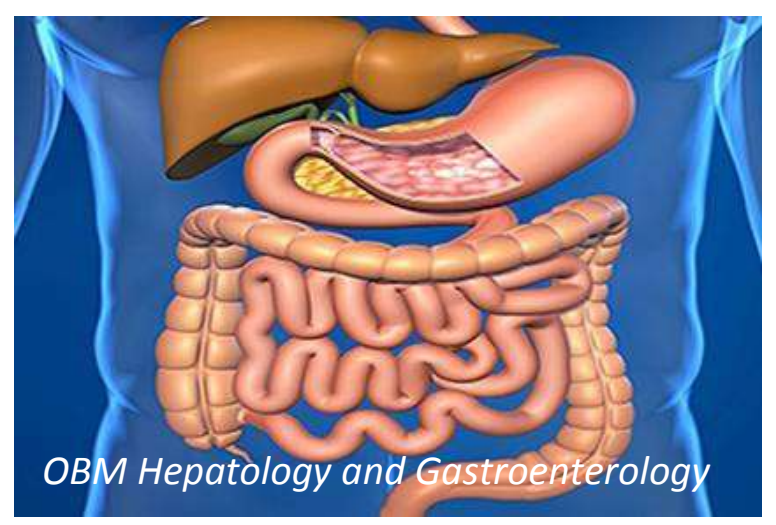

Enjoy OBM Hepatology and Gastroenterology by:

1. Submitting a manuscript

2. Joining in volunteer reviewer bank

3. Joining Editorial Board

4. Guest editing a special issue

For more details, please visit: http://www.lidsen.com/journals/hg 